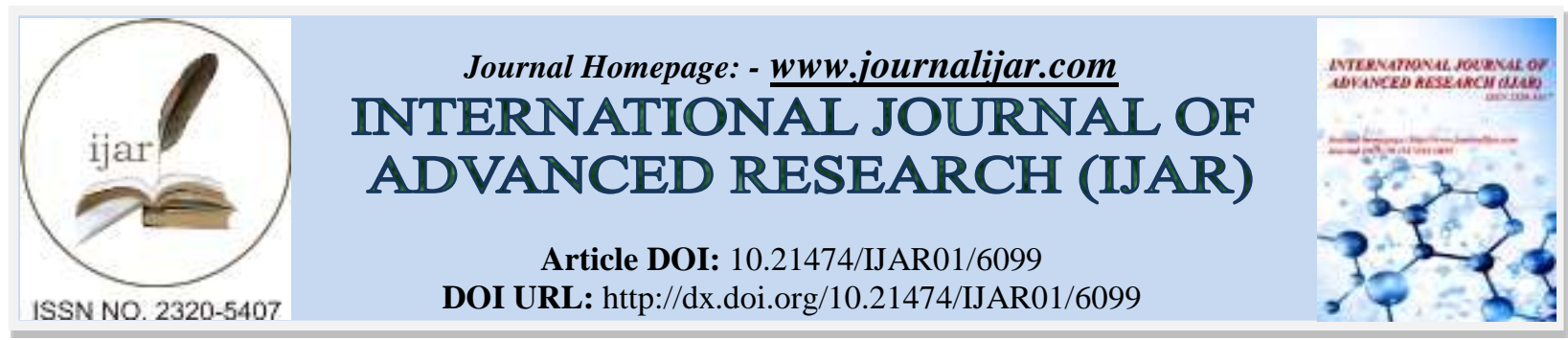

RESEARCH ARTICLE

\title{
PREVALENCE OF HUMAN PAPILLOMA VIRUS IN CERVICAL CELLS AMONG PATIENTS WITH ABNORMAL PAP SMEARS.
}

\footnotetext{
Mohammed Ibraheem Mezaal ${ }^{1}$, Dr. Ismail Husein Aziz ${ }^{2}$, Dr. Maad Mahdi Shalal ${ }^{3}$ and Dr. Nada Alwan ${ }^{4}$.

1. Ph.D. student Genetic Engineering and Biotechnology Institute for Postgraduate Studies / University of Baghdad.

2. Asst.Prof.Genetic Engineering and Biotechnology Institute for Postgraduate Studies / University of Baghdad.

3. Prof.Director of National Center for Cancer Research/ University of Baghdad.

4. Prof.College of medicine / University of Baghdad.
}

\section{Manuscript Info}

\section{Manuscript History}

Received: 19 October 2017

Final Accepted: 20 November 2017

Published: December 2017

\begin{abstract}
Human papillomavirus (HPV) is the most common viral infection of the reproductive tract. Cervical cancer is by far the most common HPV-related disease. Nearly more cases of cervical cancer can be attributable to HPV infection. This study designed foe molecular detections and genotyping of human papilloma virus (HPV) by designing methods - Endpoint real time PCR for HPV detections and genotyping of HPV 16 and 18.

The study includes 90 Pap smear samples of women suffering from abnormal Pap smears and 10 healthy women as a control, were collected from the Baghdad hospital ( Medical City), Oncology hospital and Al- Amal hospital (in Baghdad), during the period from April, 2015 to April, 2016. The age of women was ranged from 16 to 60 years. The molecular detection method (Designed PCR) in our study was showed that the $35 \%$ of women have HPV infections .
\end{abstract}

Copy Right, IJAR, 2017,. All rights reserved.

\section{Introduction:-}

Cervical cancer is a cancer arising from the cervix. It is due to the abnormal growth of cells that have the ability to invade or spread to other parts of the body. At the beginning of the process the neoplastic lesions are confined to the epithelium where there no symptoms. Later symptoms may include abnormal vaginal bleeding, pelvic pain or pain during sexual intercourse [1].

Although the incidence of cervical cancer in Iraq is relatively low (Iraqi Cancer Board, 2012 ) as in most other Islamic countries, most of the cases usually present in late advanced stages. Studies from Iraq have reported significant rates of CIN lesions among Iraqi patients complaining of gynecological problems [2] [3]. Therefore, promoting the level of awareness among the Iraqi population through screening is mandatory to control the disease.

Human papilloma virus (HPV) infection appears to be involved in the development of more than $90 \%$ of cases; most people who have had HPV infections, however, do not develop cervical cancer . Other risk factors include smoking, a weak immune system, birth control pills, starting sex at a young age and having many sexual partners, but these are less important [4]. 
The aims of this study is molecular detections of HPV-HR and genotyping by using Designed methods and .

\section{Materials and Methods:-}

\section{Subjects:-}

This study was carried out during the period between the 1st of April 2015 until the end of April 2016 within the University of Baghdad / Institute of Genetic Engineering \& Biotechnology for post Graduate Studies and the National Cancer Research Center. One study group has been investigated:

\section{Study group (With abnormal Pap smear):-}

This study has included 100 Iraqi women with different gynecologic complaints whose Pap smears revealed abnormal cytological findings. The patients were examined in the Outpatient Gynecology department of the Medical City Teaching Hospital. For each patient, a structured questionnaire containing different variables was completed .

A Healthy Control Group (a sub group from the study population) was categorized to consist of 10 healthy Iraqi women with different ages; all of whom were chosen depending on the following criteria [5] :

1. Having regular menstrual cycles in women with reproductive age (26 to 30 days)

2. Age range between 25 to 60 years

3. No history of endocrine disease

4. No use of medication or oral contraceptives.

\section{Samples collection:-}

Examined specimens were collected cells from the cervix of each women in both Patients and Healthy Control Groups.

The Papanicolaou test (abbreviated as Pap test) is a method of cervical screening used to detect potentially precancerous and cancerous processes in the cervix.

The collected cells are examined under a microscope to look for abnormalities. The test aims to detect potentially pre-cancerous changes (called cervical intraepithelial neoplasia (CIN), cervical dysplasia or squamous intraepithelial lesion system (SIL) according to the Bethesda Terminology. These lesions are often caused by sexually transmitted human papilloma viruses [6].

\section{Genomic DNA isolation:-}

Total DNA (genomic, mitochondrial, and viral) isolated from the Pap smear sample for molecular studies was applied using genomic DNA purification kits of Qiagen ( QIAamp DNA Mini Kit / Germany) . This kit has been used by other researchers in similar study [7].

\section{Agarose Gel Electrophoresis:-}

After genomic DNA extraction, agarose gel electrophoresis was adopted to confirm the presence and integrity of the extracted DNA [8].

\section{Multiplex Polymerase Chain Reaction (PCR) for HPV detections:- \\ Primer selections:-}

Multiplex polymerase Chain Reaction (PCR) for HPV type 16 and 18 - E6 gene detections were done by using a specific primer designed in our study.

The detections of L1 region for HPV as general (HPV- high risk) by using a specific primers [9].

The positive control for human beta-globin gene used in this study by using a specific primers (TAKARA company, Japan). Primers sequences are listed below, table (1) .

Table (1):- Primer sequences used in PCR amplification of E6-HPV16 and 18, L1 of HR-HPV and human betaglobin gene.

\begin{tabular}{|l|l|l|l|l|}
\hline Set & Name & Sequence $\left(\mathbf{5}^{\prime} \rightarrow \mathbf{3}^{\prime}\right)$ & Gene amplified & size \\
\hline 1a & MZNM1_F & TTGCTTTTCGGGATTATGC & E6-HPV16 & $204 \mathrm{bp}$ \\
& MZNM1_R & CAGGACACAGTGGCTTTTGA & & \\
\hline
\end{tabular}




\begin{tabular}{|l|l|l|l|l|}
\hline 2a & $\begin{array}{l}\text { MZNM2_F } \\
\text { MZNM2_R }\end{array}$ & $\begin{array}{l}\text { GTGCCAGAAACCGTTGAATC } \\
\text { TTGTGTTTCTCTGCGTCGTT }\end{array}$ & E6- HPV18 & 151 bp \\
\hline $3 \mathrm{~b}$ & $\begin{array}{l}\text { MY09 } \\
\text { MY1 }\end{array}$ & $\begin{array}{l}\text { CGTCCACAAGAGGGATACTGATC } \\
\text { GCACCAGGGATCATAACTAATGG }\end{array}$ & L1-HR_HPV & $450 \mathrm{bp}$ \\
\hline 4c & $\begin{array}{l}\text { KM29 } \\
\text { GH21 }\end{array}$ & $\begin{array}{l}\text { GGTTGGCCAATCTACTCCCAGG } \\
\text { GGAAAATAGACCAATAGGCAG }\end{array}$ & $\beta$-globin & $345 \mathrm{bp}$ \\
\hline
\end{tabular}

a : Specific primers designed

b : Specific primers used (Venceslau1 et al., 2014).

c : Specific primers (TAKARA company, Japan).

Primers have been designed in this study based on the Bioinformatics tools by using the international databases

(NCBI,EMBL-EBI and DDBJ) and a number of tools that are available on website (online tools and software).

PCR Reaction setups:-

Multiplex PCR was performed in a $30 \mu l$ total volume, as described in Table (2).

Table 2:- PCR reaction setup.

\begin{tabular}{|c|c|}
\hline Component & Reaction volume $(\mu l)$ \\
\hline $\begin{array}{c}\text { PCR Mastermix (Bioland):TaqDNA polymerase } \\
\text { dNTPs, } \mathrm{MgCl}_{2} \text { and reaction buffer }(\mathrm{pH} 8.5)\end{array}$ & $12(\mu \mathrm{l})$ \\
\hline Primer forward & $1 \mu \mathrm{l}$, total $=3 \mu 1$ \\
\hline Primer reverse & $1 \mu \mathrm{l}$ total $=3 \mu 1$ \\
\hline Template DNA & $4(\mu \mathrm{l})$ \\
\hline RNase - free water & $8(\mu \mathrm{l})$ \\
\hline Total reaction volume & $30(\mu \mathrm{l})$ \\
\hline
\end{tabular}

\section{Cycling Conditions:-}

Cycling parameters for multiplex PCR are presented in Table (3).

Table (3):- Cycling conditions for multiplex PCR .

\begin{tabular}{|c|c|c|c|}
\hline Steps & Temperature & Time & No. of cycles \\
\hline Denaturation 1 & $95^{\circ} \mathrm{C}$ & $3 \mathrm{~min}$ & 1 cycle \\
\hline Denaturation 2 & $94^{\circ} \mathrm{C}$ & $1 \mathrm{~min}$ & \multirow{2}{*}{35 cycles } \\
\hline Annealing & $55^{\circ} \mathrm{C}$ & $1 \mathrm{~min}$ & \\
\hline Extension & $72^{\circ} \mathrm{C}$ & $1 \mathrm{~min}$ & \\
\hline Final extension & $72^{\circ} \mathrm{C}$ & $5 \mathrm{~min}$. & 1 cycle \\
\hline
\end{tabular}

\section{End point RT-PCR for HPV detections:-}

The last part of the designed PCR was end point RT-PCR for HPV detections, This part was conducted for the purpose of high precision and to make sure the true positive and true negative results.

The end point RT-PCR for HPV detections part includes the same targets of the multiplex PCR (E6 gene for each HPV type 16 and type 18 , L1 gene for HPV-HR and human beta glubin) but it was replaced PCR Mastermix (Bioland) with SYBR green Mastermix (Bioland) for real time PCR with same Cycling conditions for each gene (Table 4).

Table (4):- End point RT-PCR reaction setup .

\begin{tabular}{|c|c|}
\hline Component & Reaction volume $(\mu \mathrm{l})$ \\
\hline RT-PCR SYBR green Mastermix & $10(\mu \mathrm{l})$ \\
\hline Primer forward & $1 \mu \mathrm{l}$ \\
\hline Primer reverse & $1 \mu \mathrm{l}$ \\
\hline Template DNA & $4(\mu \mathrm{l}),(0.7-3.6 \mu \mathrm{g})$ \\
\hline RNase - free water & $4(\mu \mathrm{l})$ \\
\hline Total reaction volume & $20(\mu \mathrm{l})$ \\
\hline
\end{tabular}




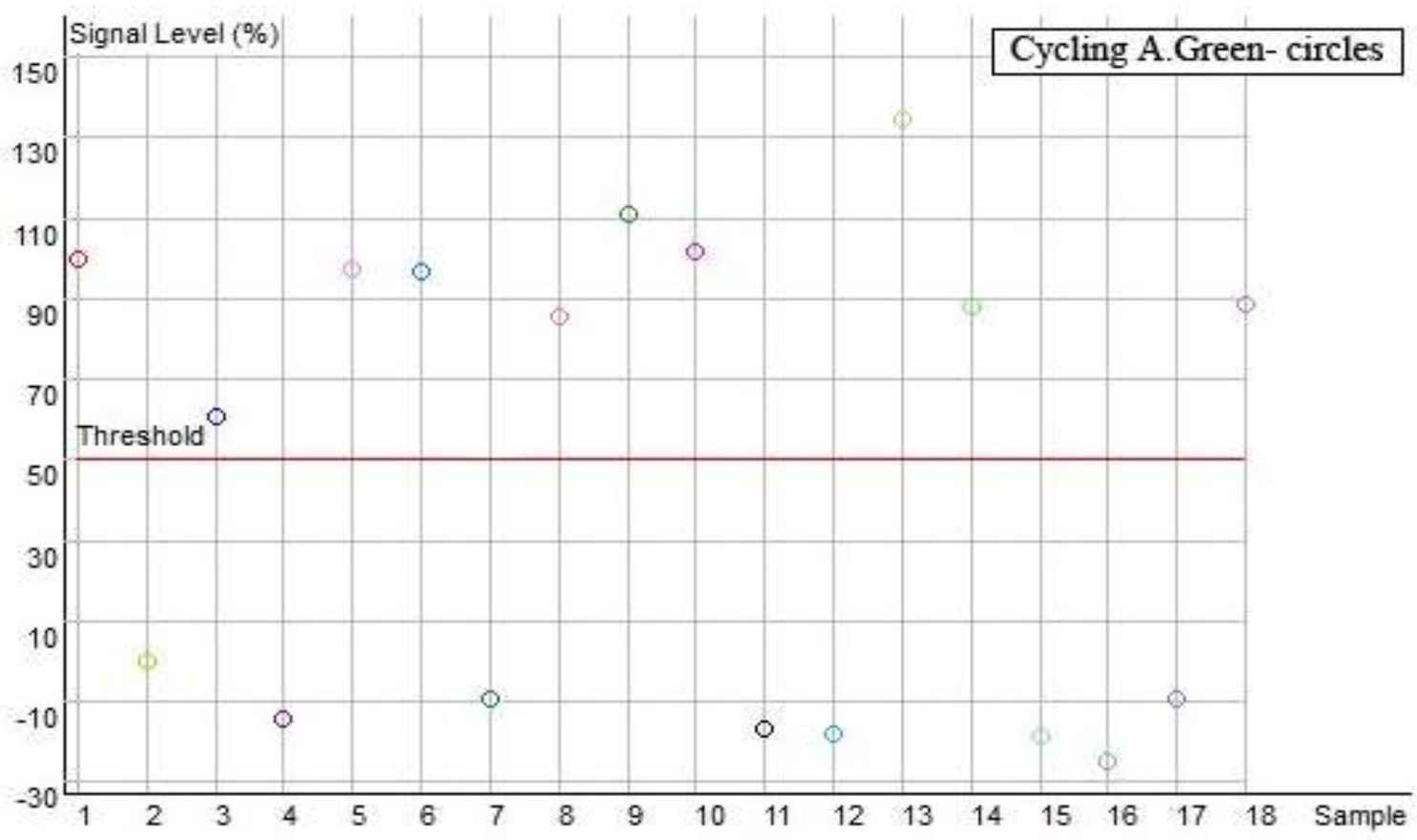

Figure (2):- The result of End point RT-PCR run for HR-HPV detections .

\section{Results and Discussion:-}

\section{Subjects data:-}

Samples of cervical cells were collected by the examining doctor from 100 Iraqi individuals through Pap smear tests. The study population was divided into two sub groups:

Sub group I (Patient Group) comprised 90 patients who visited the Gynecology Oncology clinic with different gynecologic complaints.

Sub group II (Healthy Control Group) included 10 healthy individuals with normal Pap smear findings.

\section{Age distribution of the samples:-}

The age of all women was categorized as those who were less than 30 years old versus those equal to and over 30 . (Table 5) revealed that $28 \%$ of the study women in general were less than 30 years old while $72 \%$ were equal or over 30. This points out that may leads to conclude that group 2 constituted the greatest number groups in the present study. They were two subgroups in this study, the first group the women with abnormal pap smear revealed that $28.88 \%$ of the women were less than 30 ( < 30) years and followed by $71.12 \%$ of women whose age about more than 30 years old $(>30)$ years. The second group the healthy women (with normal pap smear ) revealed that $20 \%$ of the women were about $(<30)$ years and followed by $80 \%$ of women whose age about $(>30)$ years. The results agreed with those reported by Wright (2014) who displayed that the aging is a risk factor for persistent infection. The rate of persistent high-risk infection for women older than age 40 is $50 \%$, compared with a persistence rate of $20 \%$ in women younger than age 25 .

Table (5):- Distribution of the Study Group according to Age.

\begin{tabular}{|l|l|l|l|l|l|l|l|}
\hline \multirow{2}{*}{$\begin{array}{l}\text { Group } \\
\text { NO. }\end{array}$} & \multirow{2}{*}{$\begin{array}{l}\text { Age group } \\
\text { (years) }\end{array}$} & \multirow{2}{*}{ Study group } & \multirow{2}{*}{$\begin{array}{l}\text { The sub groups } \\
\text { Nomen with abnormal } \\
\text { pap smear }\end{array}$} & \multirow{2}{*}{$\begin{array}{l}\text { Healthy women } \\
\text { (Normal) }\end{array}$} \\
\cline { 4 - 8 } & & & No. & $\mathbf{\%}$ & No. & \% \\
\hline 1 & Less than 30 & 28 & 28 & 26 & 28.88 & 2 & 20 \\
\hline 2 & More than 30 & 72 & 72 & 64 & 71.12 & 8 & 80 \\
\hline Total & $\mathbf{5 0}$ & $\mathbf{1 0 0 \%}$ & $\mathbf{9 0}$ & $\mathbf{1 0 0}$ & $\mathbf{1 0}$ & $\mathbf{1 0 0}$ \\
\hline
\end{tabular}




\section{Pap smear and sample collections:-}

The distribution of sample study according to the histology examination is show in table (6) while the distribution according to the cytology examination is illustrated in table (7).

Table 6:- Distribution of the Study Population according to Histological examination.

\begin{tabular}{|l|l|l|}
\hline Histology & Number & Percentage (\%) \\
\hline WNL & 40 & 40.00 \\
\hline CIN I & 26 & 26.00 \\
\hline CIN II & 12 & 12.00 \\
\hline CIN III & 9 & 9.00 \\
\hline Carcinoma & 3 & 3.00 \\
\hline Normal & 10 & 10.00 \\
\hline Total & 100 & $100 \%$ \\
\hline Chi-square value & --- & $11.926 * *$ \\
\hline P-value & --- & 0.00496 \\
\hline$* *(P<0.01)$. & & \\
\hline
\end{tabular}

WNL: With normal limited and CIN : Cervical intraepithelial neoplasia .

Table 7:- Distribution of sample study according to cytology .

\begin{tabular}{|l|l|l|}
\hline Cytology & Number & Percentage (\%) \\
\hline ASC-US & 21 & 21.00 \\
\hline HSIL & 18 & 18.00 \\
\hline LSIL & 20 & 20.00 \\
\hline WNL & 38 & 38.00 \\
\hline Carcinoma & 3 & 3.00 \\
\hline Total & 100 & $100 \%$ \\
\hline Chi-square value & --- & $9.337 * *$ \\
\hline P-value & --- & 0.00783 \\
\hline$* *(P<0.01)$. & & \\
\hline
\end{tabular}

WNL: With normal limited, ASC-US: Atypical squamous cells of undetermined significance, LSIL: Low-grade squamous intraepithelial lesion and HSIL : High-grade squamous intraepithelial lesion.

Fifty years ago, for squamous histology, the cervical cellular abnormalities viewed as the precursor of cervical cancer were termed mild, moderate or severe dysplasia; severe dysplasia was distinguished from the more severe diagnosis of carcinoma in situ. In the late 1960s, Richart proposed the concept of intraepithelial neoplasia [9]. CIN3 encompassed severe dysplasia and carcinoma in situ, CIN2 replaced moderate dysplasia, and CIN1 later came to include both the cytologic evidence of HPV infection (koilocytotic atypia) and mild dysplasia. The severity of the diagnosis was based on the degree of replacement of the normal stratified epithelium with mitotically active basallike epithelium $(\leq 1 / 3=\mathrm{CIN} 1, \leq 2 / 3=\mathrm{CIN} 2,>2 / 3=\mathrm{CIN} 3)$. CIN was viewed as a stepwise progression, with a high probability of transition from the more minor to more serious cancer precursors [10].

\section{Designed PCR - Multiplex Polymerase Chain Reaction and End point RT-PCR for HPV detections:-}

The present study used Multiplex Polymerase Chain Reaction and end point RT-PCR technique for HPV detections. The multiplex PCR results revealed that identical bands related to the (E6) gene for HPV type 16 and type 18, L1 region for HPV high risk and human beta glubin were present. (E6-HPV16) PCR amplified regions showed a molecular weight of $204 \mathrm{bp}$, (E6-HPV16) showed a molecular weight of $151 \mathrm{bp}$, (L1-HR-HPV) showed $450 \mathrm{bp}$ and human beta glubin about 345 bp (Figure 8) .

Emanuella et al.,(2014) showed that the L1 HPV conventional PCR products were $450 \mathrm{bp}$ and their findings were in line with the results of this study [11].

PCR is being increasingly used in clinical laboratories to diagnose HPV. In another study that used conventional PCR for HPV detections a wide range .Studies in the literature indicate variables rates of HPV detection. . This differences in detecting DNA of HPV suggest a potential difference in the ability to amplify fragments of different sizes and specific types of HPV, depending on the methods used for DNA detection, and may also be attributable to 
the difference in types of studied material (smears, frozen material, paraffin material), anatomical localization, population issue, and design of oligonucleotides [12].

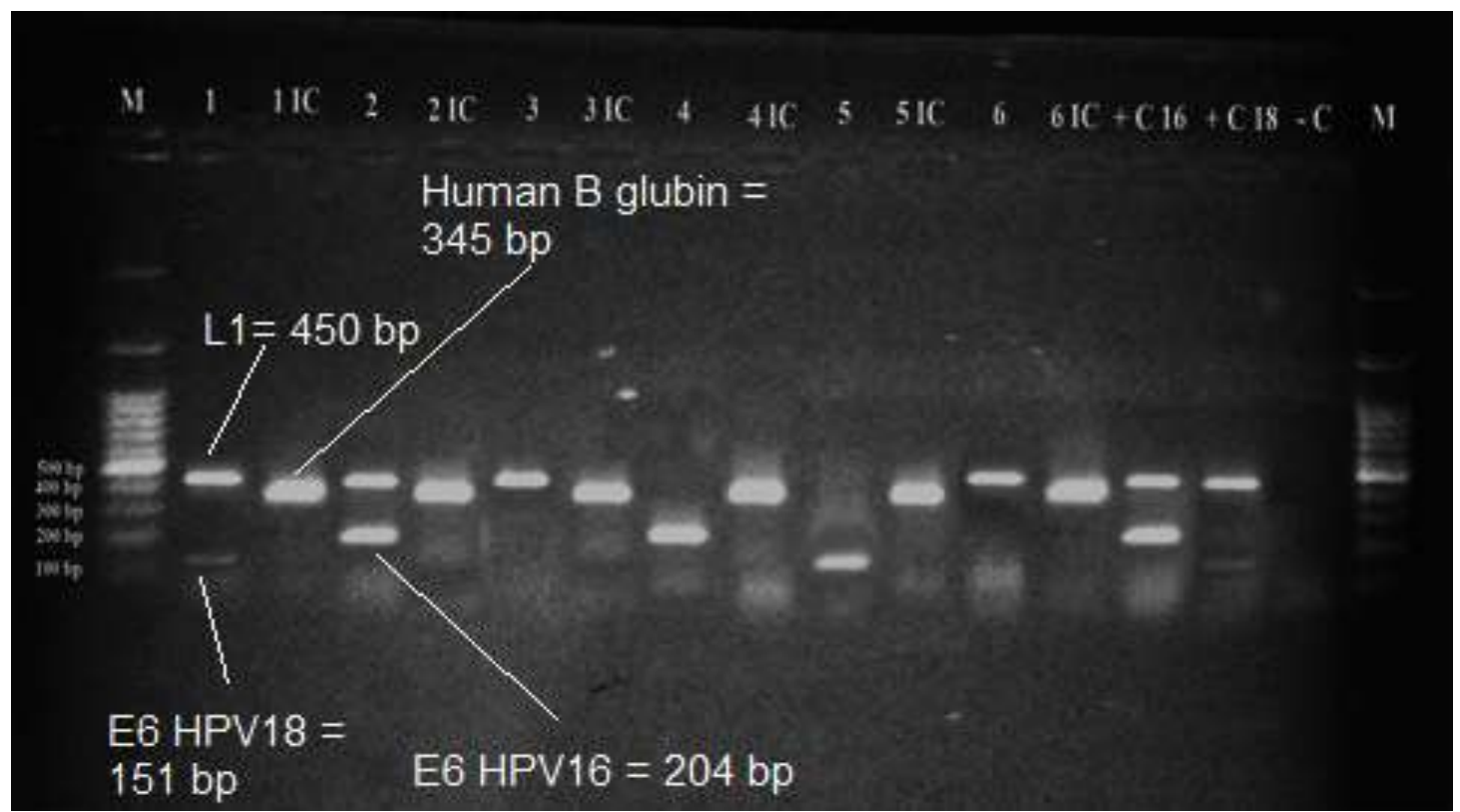

Figure (1):- Multiplex PCR products of E6 gene for each of (HPV type 16 and type 18), L1 region - HPV-HR and human beta glubin on $2 \%$ agarose gel at 75 voltages for $(45-50) \mathrm{min}$.

$\mathbf{M}=$ Marker (100 bp ladder),$-\mathbf{C}=$ Negative control,$+\mathbf{C}=$ Positive control and $\mathbf{I C}=$ Internal control

The last part of the designed PCR was (End point RT-PCR for HPV detections), This part was conducted for the purpose of high precision and to evaluate and confirm the true positive and true negative results.

The end point RT-PCR for HPV detections part includes the same targets of the multiplex PCR (E6 gene for each HPV type 16 and type 18, L1 gene for HPV-HR and human beta glubin) (Figure 2) (Table 8).

Table 8:- The keys of End point RT-PCR Run Results .

\begin{tabular}{|l|l|l|l|l|l|}
\hline No. & Colour & Name & Type & Genotype & Cycling A.Green \\
\hline 1 & & + C & Positive Control & & Reaction \\
\hline 2 & & - C & Negative Control & & No Reaction \\
\hline 3 & & P1-HPV 18 - E6 & Unknown & & Reaction \\
\hline 4 & & P1-HPV 16- E6 & Unknown & & No Reaction \\
\hline 5 & & P1-HPV HR - L1 & Unknown & & Reaction \\
\hline 6 & & P1-Human B glubin & Unknown & & Reaction \\
\hline 7 & & P2-HPV 18 - E6 & Unknown & & No Reaction \\
\hline 8 & & P2-HPV 16 - E6 & Unknown & & Reaction \\
\hline 9 & & P2-HPV HR - L1 & Unknown & & Reaction \\
\hline 10 & & P2-Human B glubin & Unknown & & Reaction \\
\hline 11 & & P3-HPV 18 - E6 & Unknown & & No Reaction \\
\hline 12 & & P3-HPV 16 - E6 & Unknown & & No Reaction \\
\hline 13 & & P3-HPV HR - L1 & Unknown & & Reaction \\
\hline 14 & & P3-Human B glubin & Unknown & & Reaction \\
\hline 15 & & P4-HPV 18 - E6 & Unknown & & No Reaction \\
\hline
\end{tabular}




\begin{tabular}{|l|l|l|l|l|l|}
\hline 16 & & P4-HPV 16 - E6 & Unknown & & No Reaction \\
\hline 17 & & P4-HPV HR - L1 & Unknown & & No Reaction \\
\hline 18 & & P4-Human B glubin & Unknown & & Reaction \\
\hline
\end{tabular}

It was illustrated that four negative results (in multiplex PCR) turned out to be positive (in end point RT-PCR), and therefore the total number of positive results by using multiplex PCR technique was 31/100. On the other hand, the total number of positive results by using end point RT-PCR technique was 35/100. The number and percentage of positive and negative results are shown in table (9).

The E6 gene for HPV 16 and HPV 18 was screened by sequencing from women samples. The determination of the sequences were for the purpose of proving the identity of the virus (HPV 16 and HPV 18) with international references.

All results were directly compared with human reference - E6 sequences (http:NCBI Reference Sequence) directly.

The E6 gene for HPV 16 and HPV 18 sequences have been published in the international databases :

1. NCBI (National Center for Biotechnology Information)

2. ENA-EBI (European Nucleotide Archive)

3. DDBJ (DNA Data Bank of Japan).

Table (9):- The number and percentage of results by using multiplex PCR and End point RT-PCR for HPV detections.

\begin{tabular}{|l|l|l|l|l|}
\hline \multirow{2}{*}{ Results } & \multicolumn{2}{|l|}{ multiplex PCR } & \multicolumn{2}{l|}{ End point RT-PCR } \\
\cline { 2 - 5 } & No. & $\%$ & No. & \% \\
\hline Positive & 31 & 31.00 & 35 & 35.00 \\
\hline Negative & 69 & 69.00 & 65 & 65.00 \\
\hline Total & 100 & 100 & 100 & 100 \\
\hline
\end{tabular}

Real-time PCR is carried out in a thermal cycler with the capacity to illuminate each sample with a beam of light of at least one specified wavelength and detect the fluorescence emitted by the excited fluorophore. The thermal cycler is also able to rapidly heat and chill samples, thereby taking advantage of the physicochemical properties of the nucleic acids and DNA polymerase. Then the reaction is run in a real-time PCR instrument, and after each cycle, the intensity of fluorescence is measured with a detector; the dye only fluoresces ( such as dsDNA dyes - SYBR Green) will bind to all dsDNA PCR products. This method has the advantage of only needing a pair of primers to carry out the amplification, which keeps costs down and more sensitivity and high accuracy for real time PCR than conventional PCR [12].

\section{Conclusions:-}

1. In this study a new method has been been developed of high precision and more sensitivity for early detection of human papilloma virus (HPV) the main cause of cervical cancer compared with the global diagnosis kit (Sacace, Italy).

2. The study found variation in the results of PCR (RT-PCR/Sacace, Italy and designed PCR) for HPV detection depending on the histological and Cytological examinations . 


\section{References:-}

1. Tarney, C. and Han, J. (2014). Postcoital bleeding: a review on etiology, diagnosis, and management. Obstetrics and gynecology international . PMID : 192087. 25045355.

2. Al-Alwan, N. (1995). The Fate of Mild Cervical Dysplasia: a long-term cytologic follow-up study of 252 patients. J. Fac. Med. Baghdad Univ.; 37: 237-244).

3. Al-Alwan, N. (2001). Colposcopy, Cervical Cytology and Human Papillomavirus Detection as Screening tools for Cervical Cancer. Eastern Mediterranean Health Journal, WHO, EMRO, 7 (1/2): 100-105.

4. Kufe, D. (2009). Holland-Frei cancer medicine. (8th ed.). New York: McGraw-Hill Medical. p. 1299. ISBN 9781607950141.

5. Michael,F. ; Charlotte, C. ; Sun,L. Schover, M. ; Munsell, A. ; Taylor, W. ; Patricia E. ; Therese, B. ; Charles, F. ; Levenback,C. ; David, M. and Diane,C. (2005). Quality of Life and Sexual Functioning in Cervical Cancer Survivors. Journal of Clinical Oncology. VOL. 23 , No. 30 :7428-7436.

6. Moyer,V. ; Preventive, U. and Task, F. (2012). Screening for cervical cancer: U.S. Preventive Services Task Force recommendation statement. Annals of internal medicine 156 (12): 880-91, W312.

7. Brestovac, B. ; Wong, M. ; Costantino, P. and Groth, D. (2014). A rapid DNA extraction method suitable for human papillomavirus detection. J Med Virol. 653-7. doi: 10.1002/jmv.23882.

8. Sambrook, J. (1989). Molecular Cloning: A Laboratory manual. Second Edition. (Plainview, New York: Cold Spring Harbor Laboratory Press).

9. Venceslau1 E.; Bezerra, M.; Lopes, A.; Souza, É.; Onofre, A. ; De Melo C.; Jeraldo ,V. and Onofre, F.(2014). HPV detection using primers MY09/MY11 and GP5+/GP6+ in patients with cytologic and/or colposcopic changes. J Bras Patol Med Lab, v. 50, n. 4, p. 280-285.

10. [9]. Richart, R. (1972). Proceedings: An assessment of the biology of cervical intraepithelial neoplasia. Proc Natl Cancer Conf. 7:219-22.

11. Mark, S. and Nicolas, W. (2013). Human papillomavirus (HPV) infection and the multi-stage carcinogenesis of cervical cancer. Cancer Epidemiol Biomarkers Prev. 22(4): 553-560. doi:10.1158/1055-9965.EPI-12-1406.

12. Emanuella, M.; Mauro, M.; Anna, C.; Érick, V.; Alexandre, S.; Claudia, M.; V. ; Fabiana, B.(2014). HPV detection using primers MY09/MY11 and GP5+/GP6+ in patients with cytologic and/or colposcopic changes. $J$ Bras Patol Med Lab, v. 50, n. 4, p. 280-285.

13. Demathe, A. (2010). Comparação entre dois métodos de detecção de DNAde papilomavírus humano em carcinoma epidermoide de lábio. J BrasPatol Med Lab, v. 46, n. 2, p. 85-90.

14. Julie, L. ; Kirstin, E. and Nick, S. (2009). Real-Time PCR Current Technology and Applications. Caister Academic Press. ISBN 978-1-904455-39-4. 